\title{
CONTRIBUTION OF PRODUCERS' ORGANIZATIONS TO THE REALIZATION OF SOCIO-COMMUNITY INFRASTRUCTURES IN THE COMMUNE OF BANIKOARA
}

\author{
ASSOUNI Janvier \\ Department of Geography and Land Management, University of Parakou (Benin) \\ https://doi.org/10.35410/IJAEB.2021.5672
}

\begin{abstract}
In Sub-Saharan African countries in general and in Benin in particular, producer organizations play an important role in the realization of socio-community infrastructure. This research examines the contribution of producers' organizations to the realization of socio-community infrastructure in the commune of Banikoara.

The methodological approach adopted is based on documentary research, field surveys, data processing and analysis of results using the SWOT model. Within the framework of this research, 250 people were surveyed.

The research revealed that the commune of Banikoara has 228 producer organizations spread throughout the commune. These producer organizations mobilize funds for the construction of socio-community infrastructure. $98 \%$ of the socio-community infrastructure built in the municipality of Banikoara is financed by producers' organizations. However, these producers' organizations face difficulties that limit their contribution to the construction of sociocommunity infrastructure. These difficulties include a lack of technical supervision, poor governance, and abandonment or failure to carry out the work. Faced with this situation, it is important to work on the organization of other agricultural sectors. Similarly, the communal authorities must commit to working in symbiosis with producers and help them achieve their goals.
\end{abstract}

Keywords: Banikoara, contribution, socio-community infrastructure, producer organization, decentralization.

\section{INTRODUCTION}

Africa's economic growth potential depends largely on the agricultural sector. Consequently, all development models should give pride of place to the agricultural sector as an engine of economic growth (M. Gibigayé Adam, 2008, p. 13). The issue of development is of growing concern to the international community. Analyzed from several angles that are intertwined with each other, it always highlights the role and actions of multiple actors involved (A. S. Afouda, 2016, p. 77). The quest to improve the living conditions of the people has always been the major concern of all rulers. The major economic, political and environmental changes in the last three decades have had a major impact on the role played by the various stakeholders in agricultural and rural development. In the face of poverty, and in order to achieve the well-being of their populations, States are implementing various development strategies. Unfortunately, many states in poor African countries cannot guarantee effective and universal public services to their people, nor can they finance major infrastructure investments to ensure development (M. Guire, 2009 
p.2). Decentralization in West Africa did not really take off until the 1990s when the movement to dismantle states was accelerated under pressure from donors (Y. Ilboudo, 2009, p.13).

Since then, a wide range of producer organizations, mainly cooperative structures, have emerged. These producer organizations are increasingly considered as key development actors (A. Elbehri and M. Lee, 2011, p. 9). Long marginalized, producers' organizations have received special attention since the beginning of decentralization. Indeed, according to A. S. Afouda et $a l$, (2008, p. 10), they are an essential instrument of collective action in rural areas. In fact, the significant changes in the socio-economic and political context have brought about new challenges and issues that producers and their organizations must now face.

In Benin, the State began the process of decentralization in 1993. In this new management system, the State has transferred many powers to the communes to enable them to take firm charge of their destiny. These communes now have the heavy responsibility of ensuring the functioning of their administration and meeting the expectations of their populations in terms of local public facilities as well as economic and social development needs (G. Orou and F. Alou, 2014, p.7). The communes must rely on themselves to resolve the thorny issue of financial resources essential to their operation and development (H. L. F. Fiogbé, 2017, p. 8)

The reality is that some communes in Benin rely on the assistance of producers' organizations to implement some equipment in their respective communes. The commune of Banikoara, which is the subject of this research, remains the leading cotton producer in Benin. It benefits from the assistance of these producers' organizations. The objective of this research is to analyze the contribution of producers' organizations in the realization of socio-community infrastructures in the commune of Banikoara.

\subsection{Presentation of the geographical framework}

The commune of Banikoara is located in the department of Alibori between $11^{\circ} 18^{\prime} 00^{\prime \prime}$ north latitude and $2^{\circ} 26^{\prime} 00^{\prime \prime}$ east longitude. It is bordered to the North by the Niger River, to the South by the Borgou Department, to the East by Nigeria and to the West by the AtacoraDepartment and Burkina-Faso. Banikoara is located in the North-West of Benin. It is bordered to the North by the commune of Karimama, to the South by the communes of Gogounou and Kérou, to the East by the commune of Kandi and to the West by Burkina Faso. Banikoara has nine rural districts (Founougo, Gomparou, Goumori, Kokey, Kokiborou, Ounet, Sompérékou, Soroko and Toura) and one urban district (Banikoara). It covers an area of $4,383 \mathrm{~km}^{2}$. The commune has 69 villages and city districts (figure 1). 


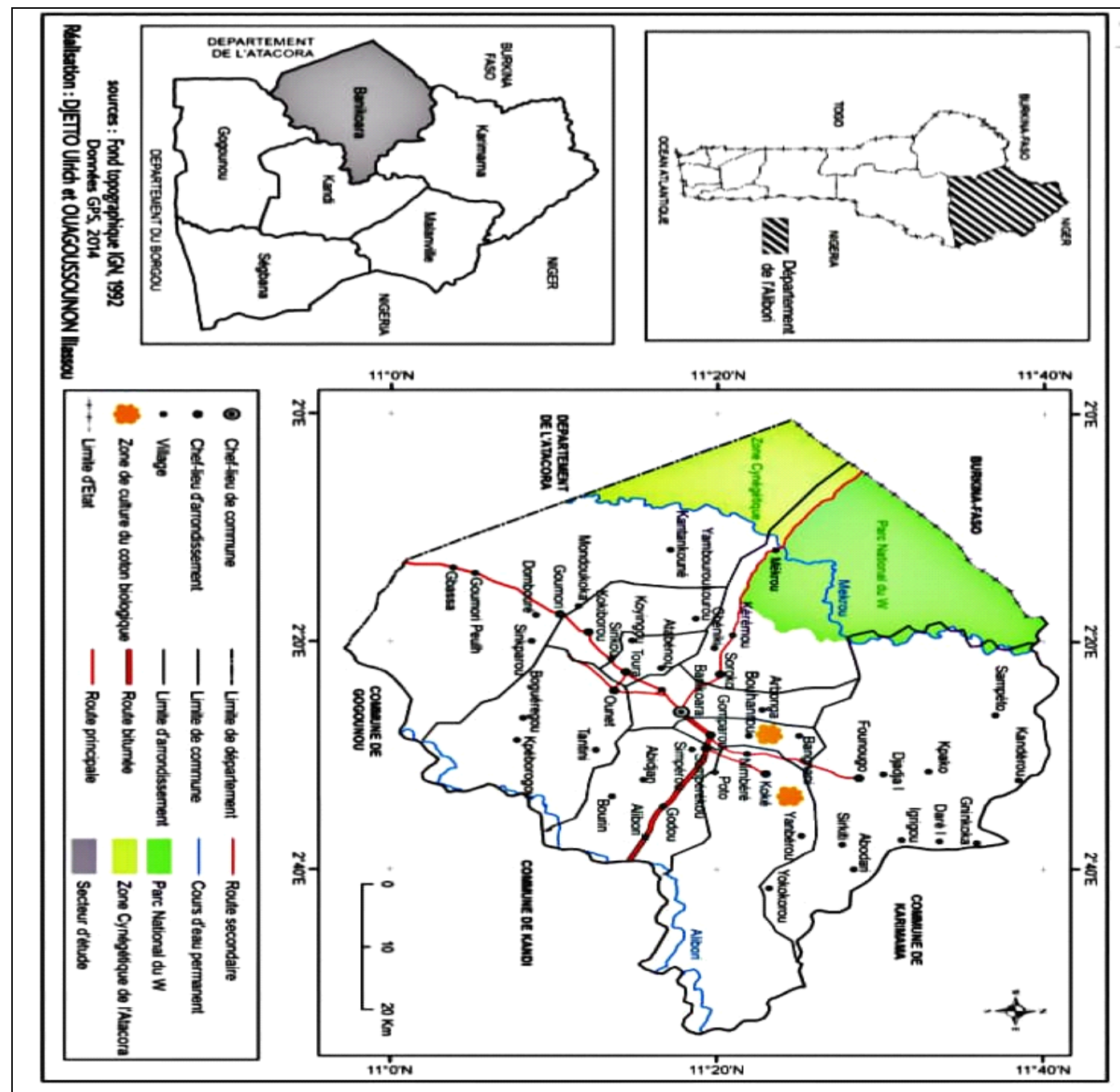

Figure 1: Geographical location of the commune of Banikoara

\section{METHODOLOGICAL APPROACH}

The methodological approach adopted was based on documentary research and data collection in the field.

\subsection{Data used}

Several data were used. These are:

- Socio-anthropological data concerning qualitative information gathered from surveys of producers' organizations in the commune of Banikoara;

- Socio-economic data relating to the economic activities of the organizations, the areas of intervention of these producer organizations, the financial resources mobilized for each agricultural season, the problems faced by these producer organizations. 
Vol. 06, No. 05; 2021

ISSN: $2456-8643$

\subsection{Sampling}

The sample size is determined by the formula $\mathrm{n}=\mathrm{Z}^{2} \mathrm{x} \mathrm{px} 1-\mathrm{p} / \mathrm{i}^{2}$

with n: sample size; Z: a constant equal to 1.96 for a confidence level of $95 \%$; p: proportion of agricultural producers in relation to the total population of the commune of Banikoara (approximately 98\%); i: margin of error set at 6\%.

$\mathrm{n}=(1.96)^{2} \mathrm{X}(0.98) \times(0.2) /(0.06)^{2}=209.15210$.

$=210$ agricultural producers surveyed.

In addition to these farmers, there were 30 leaders of producers' organizations, 5 agents of the Communal Sector for Agricultural Development and 5 local elected officials. In total, 250 people were surveyed as part of this research.

\subsection{Data collection techniques and tools}

The following techniques were used for data collection. These are:

- Direct observation and systematic visit of all the socio-community infrastructures built in the commune

- Direct contact with producer organizations, local authorities

- Focus groups in the district capitals for additional information on the initiatives undertaken for the realization of socio-community infrastructures.

The collection tools used for this purpose are the observation grid and the interview guide.

\subsection{Data processing and analysis of results}

The collected data were processed through descriptive and analytical statistics. Word 2013 and Excel 2013 software were used for data entry and statistical processing, making charts, tables. The analysis of the results is done with the help of SWOT model (Strenghs, Weaknesses, Opportunities and Threats).

\section{RESULTS}

\subsection{Producer organizations in the commune of Banikoara}

In order to defend their interests with other actors, producers form producer organizations. The commune of Banikoara has 228 producer organizations spread throughout the commune.

The results of the field surveys show that $96 \%$ of producer organizations are created on the initiative of the members of the organization. The objectives of these producer organizations are to carry out income-generating activities. Their role is to benefit from supervision, work more easily and obtain loans.

$90 \%$ of these organizations have received technical training or financial support from various organizations: Communal Sector for Agricultural Development, Swiss Cooperation, ADESCANGO, DEDRAS, etc. These training sessions focused on financial management, production techniques, product conservation, group work, etc.

Thanks to these trainings, the members of these organizations were able to master new techniques and production methods and then the organization of several general assemblies. These producers' organizations mobilize funds for the construction of socio-community infrastructures, which contributes to the development of the localities of the commune.

\subsubsection{Mobilization of financial resources}


Vol. 06, No. 05; 2021

ISSN: $2456-8643$

In addition to direct contributions, the dividends from the sale of agricultural products, especially cotton, constitute the main financial source of the farmers' organizations for the financing of socio-community development initiatives in the commune of Banikoara. Indeed, at the end of each agricultural season, producers' organizations may or may not receive an additional amount of the market value of agricultural products, especially seed cotton, that is actually produced and marketed. This surplus is paid in the form of rebates and is paid directly into the account of each producer organization that manages it. As regards the mobilization of financial resources in this commune, two periods are to be considered: the first period from 1995-2012 and the second period from 2013-2019.

From 1995 to 2012, the mobilization of financial resources by producer organizations reached a cumulative fund of 191833840 FCFA. From 2013-2019, the financial resources have reached a cumulative fund of 723010048 FCFA.

Figure 2 illustrates the evolution of the financial mobilization of producer organizations from 1995-2019.

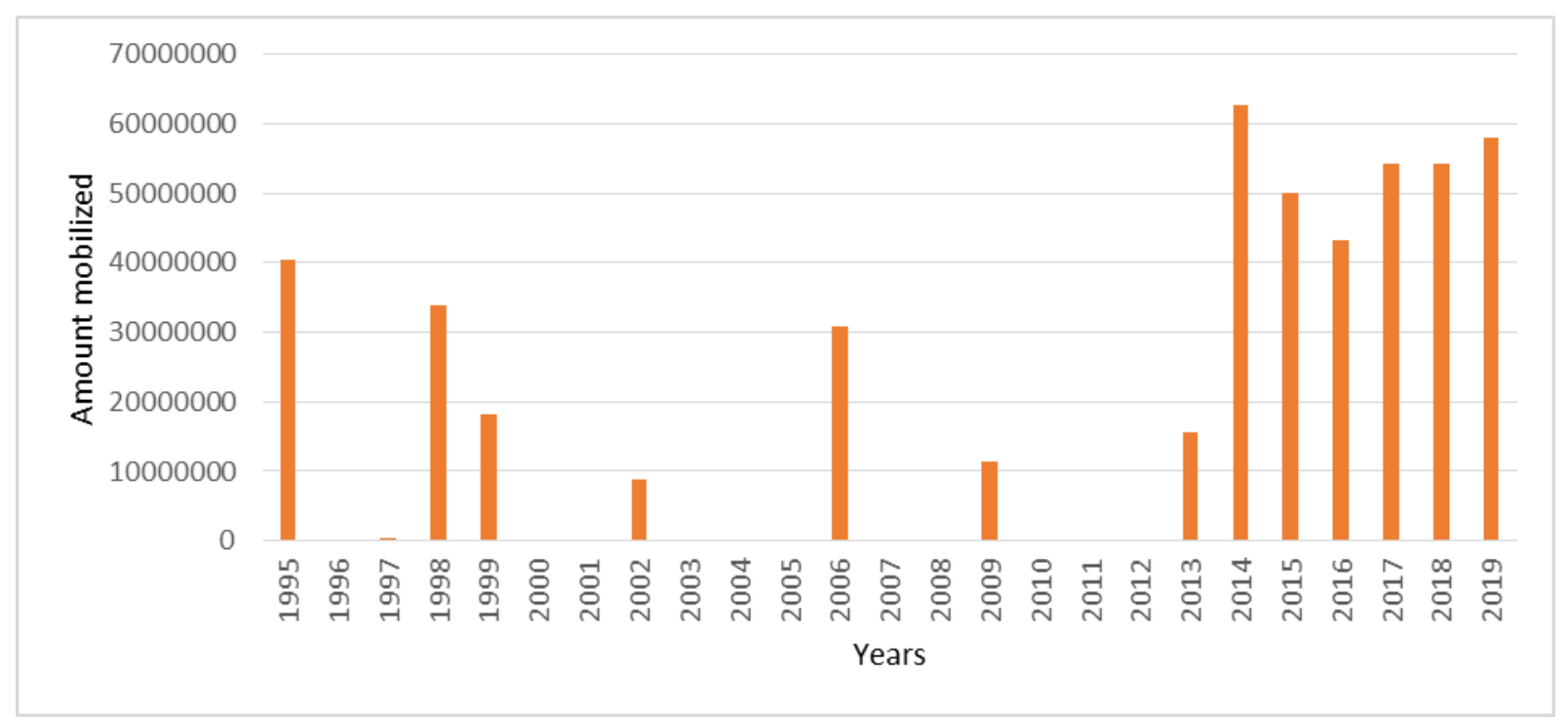

Figure 2: Mobilization of financial resources by producer organizations in the commune of Banikoara

Figure 2 shows that during the period 1995 to 2012, there was very little mobilization of financial resources. On the other hand, the mobilizations are significant in 1995, 1998, 2006 and less significant in 1996, 2000, 2001. However, it should be noted that the most important mobilization for this period was in 1995 with an amount of 40442000FCFA.

From 2013-2019, the mobilization was more important and increases from year to year. Thus, the importance of mobilizations was observed in 2014 with an amount of 62770000FCFA. Nevertheless in 2013 the achievements are less important.

This table shows that the financial mobilization of producers' organizations in the commune varies according to cotton production during the season. The higher the production, the higher the mobilization. This is easily seen in the 2013-2014 and 2014-2015 cotton seasons, where the amount mobilized is much higher than in the other years. This can be explained by the 
enthusiasm of farmers due to government incentives, the supply of good quality inputs and fertilizers and the improvement in the selling price of cotton.

These financial mobilizations of producers' organizations are then made available to the town hall for the realization of socio-community infrastructures. These funds are used to finance development works or actions in the commune.

\subsubsection{Participation of producers' organizations in the construction of socio-community infrastructures in the commune of Banikoara}

According to $97 \%$ of the producers surveyed, the producers' organizations are able to participate directly in the communal budget thanks to the taxes collected by the town hall on all cotton production during the agricultural seasons. For them, in addition to these taxes, the dividends from the sale of agricultural products are used to build socio-community infrastructure in the commune.

\subsubsection{Administrative facilities}

With the rebates, the producers' organizations finance the construction of infrastructure enabling the population to benefit from the services and other benefits of the local administration. Thus, the results of field surveys have shown that the construction of buildings for the Banikoara town hall, the housing for the principals of the Sompérékou, Kokey and Founougo secondary schools.

\subsubsection{Health and socio-educational facilities}

According to the results of field surveys, $97 \%$ of the commune's social and health infrastructure was built thanks to contributions from producers' organizations. Thus, in the commune of Banikoara, two health centres have been built in the Sompérékou district at a cost of 25,650,492 FCFA. These infrastructures now allow the population to benefit from acceptable health care.

As for educational infrastructure, field surveys have shown that the commune of Banikoara has 452 classrooms overall, $3 / 4$ of which were final materials in 2016. According to the data collected in the field, producers' organizations have taken a significant financial share in the realization of school infrastructures thanks to the earnings from the sale of agricultural products especially cotton. During the construction of classroom modules, producer organizations disbursed 1000510510 FCFA for 29 modules of 76 classrooms. Photos 1 and 2 show some of the school infrastructure built in the commune of Banikoara by producers' organizations.

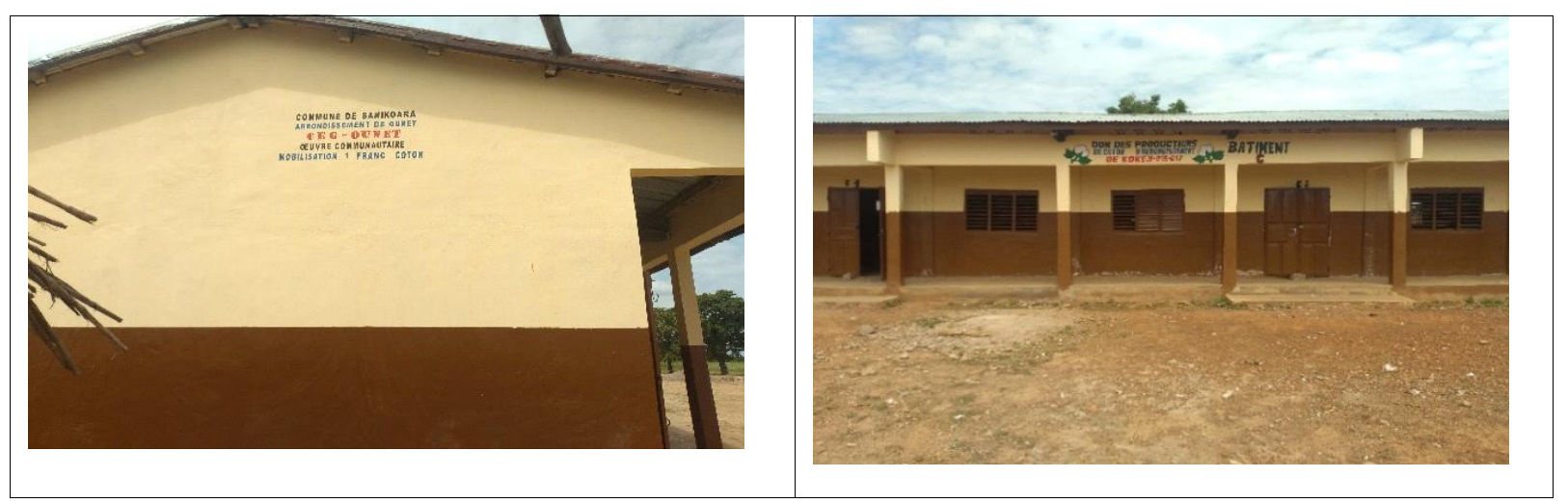


Photo 1: Classroom module at CEG Ounet

Shooting : Ouagoussounon, October 2019
Photo 2: Classroom module at CEG Kokey Shooting: Djetto, October 2019

Photo 1 shows a classroom module at CEG Ounet, built by the town hall but financed by the producers' organizations of the commune of Baniokara. Photo 2 shows a classroom module at CEG Kokey, built by the town hall and financed by the producers' organizations of the commune.

\subsubsection{Water supply and sanitation works}

Ninety-five percent of the water supply structures are water pumps and large diameter wells. The commune has a rural water supply network in Kokey that has been operational since 2010 on the initiative of the people.

In terms of sanitation, efforts have been made with the construction of 90 family latrines in the localities and colleges of the commune. For example, at the Ounet secondary school, latrines have been built with the contribution of producers' organizations to the tune of 300,000 FCFA.

\subsubsection{Storage facilities for agricultural products and inputs}

The conservation of agricultural products requires the construction of warehouses by the population and producers' organizations. All the districts have benefited from the construction of at least two warehouses for storing agricultural products and inputs. Thus, in the Gomparou district, two warehouses were built at a total cost of CFAF 250,000, financed by the producers' organizations. In Sompérékou, four stores were built at a total cost of 40442000 FCFA. The store in Ounet cost CFAF 7,600,000 and the store in Toura cost CFAF 9,290,348. Photo 3 shows the Sompérékou store.

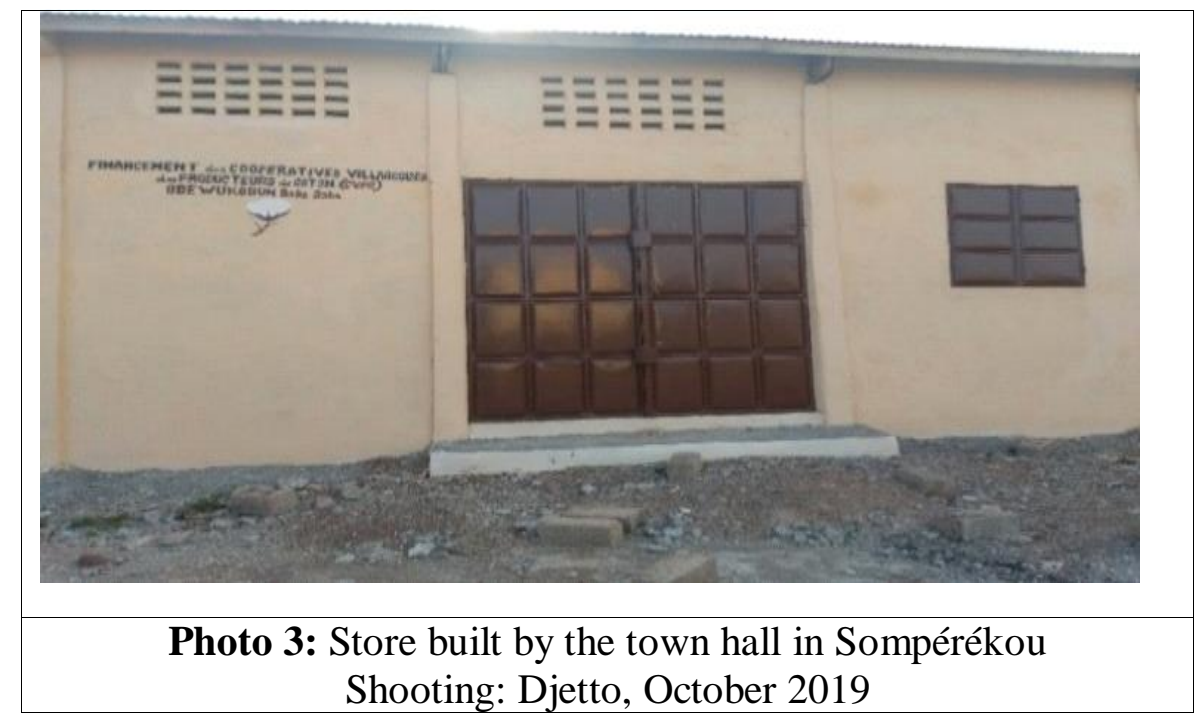

Photo 3 shows a shop in Sompérékou built by the town hall with funding from producer organizations in the commune.

\subsubsection{Rehabilitation of rural roads and construction of bridges}


According to investigations, the commune of Banikoara is one of the most poorly served communes in Benin in terms of communication networks. Access to some villages remains difficult, especially during the rainy season. Faced with this situation, local initiatives have been taken by the population to rehabilitate and maintain rural access roads with the support of financial partners. According to the results of field surveys, the fundraising strategy for local financing consisted of a levy of $1 \mathrm{~F} \mathrm{CFA} / \mathrm{kg}$ to each cotton producer throughout the commune. In 2012, a bridge made of precarious materials was built in the Kokey district at a cost of $200780 \mathrm{~F}$ CFA.

\subsubsection{Location of socio-community infrastructures financed by producers' organizations}

In the commune of Banikoara, several socio-community infrastructures have been built with funding from producers' organizations. Figure 3 presents the list of socio-community infrastructures built in this commune by the town hall and financed by the producers' organizations. 
International Journal of Agriculture, Environment and Bioresearch

Vol. 06, No. 05; 2021

ISSN: $2456-8643$

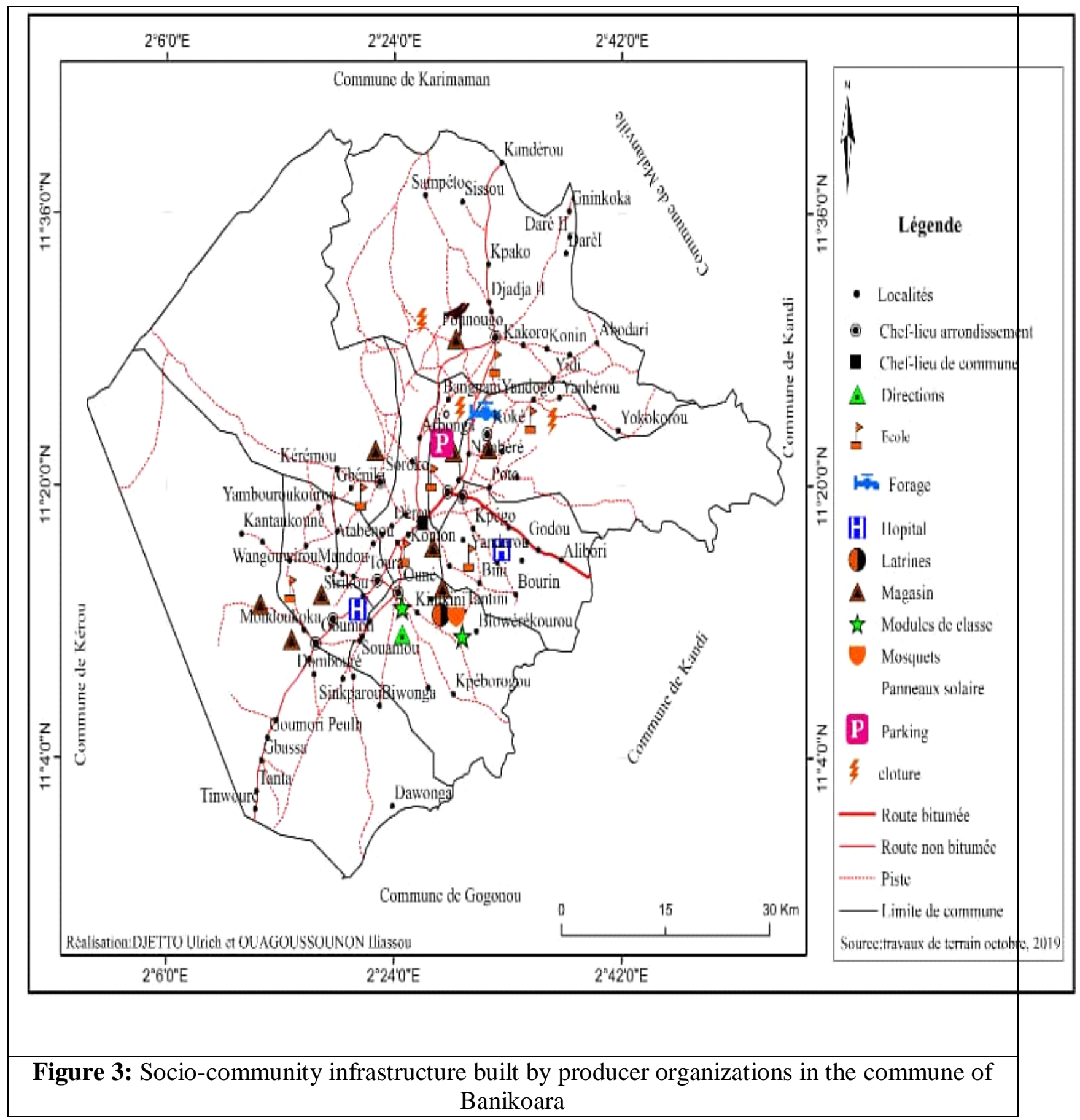

Figure 3 shows the socio-community infrastructures financed by the producers' organizations in the commune and carried out by the Banikoara town hall.

95\% of the respondents recognized the effectiveness of the producers' organizations and affirmed that the achievements of the producers' organizations have contributed greatly to the improvement of the living conditions of the people of the commune of Banikoara. 
The various infrastructures built are managed and maintained by the beneficiary populations with the help of these producers' organizations.

\subsection{Constraints to the contribution of producer organizations in Banikoara}

Producer organizations face difficulties in their activities in the commune. These difficulties reduce the contribution of producer organizations to the realization of socio-community infrastructures.

\subsubsection{Lack of technical support}

According to the results of the field surveys, all the producers' organizations are supervised by the agents of the Secteur Communal pour le Développement Agricole (SCDA)-Banikoara. These agents do not manage to cover the entire commune. Thus, $75 \%$ of the producers surveyed stated that the training and supervision provided by these agents is no longer regular and not all the producers' organizations benefit from this training and technical assistance, which is a serious blow to the effectiveness of these producers' organizations.

\subsubsection{Poor governance}

According to $92 \%$ of the producers surveyed, the major obstacle for producer organizations is the misappropriation of community funds and assets. Indeed, $80 \%$ of producer organizations are subject to such mismanagement.

For all the leaders of the producers' organizations surveyed, the problems from which the producers' organizations suffer are essentially the accumulation of unpaid cotton production, which plunges the organizations into a spiral of indebtedness, and the poor distribution of income from the sale of agricultural products among the members of the organizations.

$89 \%$ of the producers surveyed said that the heads of the organizations take advantage of this inextricable situation to misappropriate the meagre income of the producers, which arrives in dribs and drabs, by making the producers believe that these payments have not arrived. According to them, these managers are squandering the funds of the producers' organizations.

\subsubsection{Abandonment or failure to carry out work}

In the commune of Banikoara, construction projects for socio-community infrastructure have encountered enormous difficulties in their implementation. According to the results of field surveys, $67 \%$ of the sites were abandoned by the contractors. This is the case of the construction site of a storage warehouse for agricultural products in Ounet for an amount of 7600000 FCFA launched in 2006 was abandoned by the contractor. It took the mobilization of the population before the construction site was completed in 2016.

$54 \%$ of the construction sites launched do not respect the specifications and have experienced failures in the implementation in the commune. This is the case of the construction site of the residence of the Director of the Founougo College for an amount of 6794600 FCFA.

These constraints limit the contribution of producer organizations to the realization of sociocommunity infrastructures and do not encourage them to finance works of community interest.

Faced with this situation, it is imperative that the communal authorities support and accompany the producers' organizations to ensure efficient financial management. They must work to make 
Vol. 06, No. 05; 2021

ISSN: $2456-8643$

these organizations more dynamic and diversify the sources of funding for socio-community infrastructure.

\section{DISCUSSION}

The commune of Banikoara has 228 producer organizations spread throughout the commune. These producer organizations are organizations that defend the interests of producers. This result is consistent with that of Y. A. Tohozin (2008, p. 54) who believes that producers group together to defend their interests with other actors in the sector.

Producers' organizations participate in the development of the commune of Banikoara. This result confirms the work of Y. Ilboudo, (2009 p59) who states that village communities are becoming increasingly aware of the need to get involved in the development of the country. This result is similar to that of Y. A. Tohozin $(2008$, p. 56) who states that producers' organizations are actively involved in building socio-community infrastructures necessary for the enhancement of human capital, the cornerstone of any development process.

Producer organizations in the commune of Banikoara face constraints that hinder their contribution to the realization of socio-community infrastructures in this commune. This result confirms the work of U. E. M. Djetto and I. Ouagoussounon (2020, p. 44) who believe that producers' organisations face significant difficulties in their leading role and their need to respond to the needs of their communities.

Faced with this situation, it is important to perpetuate and diversify the sources of financing and to organize other agricultural sectors.

\section{CONCLUSION}

The commune of Banikoara has a total of 228 producer organizations registered with UcomCVPC-Banikoara. These producer organizations make a significant effort to help the commune. Thus, important financial resources are mobilized by these producer organizations for the production and marketing of agricultural products for the realization of socio-community infrastructures in the commune. These producers' organizations remain credible partners for the financing and implementation of local development actions. Thus, the achievements made in the commune of Banikoara contribute to the improvement of the living conditions of the population. The socio-economic efficiency of producers' organizations, especially cotton producers, is obvious. However, it is important to work on the organization of other agricultural sectors in order not only to diversify the sources of funding for local development actions or works, but also to make producers less dependent on cotton monoculture.

These organizations could better contribute to the development of the commune if they were not faced with natural, organizational and technical constraints. Also, effective participation of the various parties is necessary in order to strengthen the production and resource mobilization capacities for the development of the commune.

For a better contribution of the producers' organizations in the commune, the communal authorities must commit to working in symbiosis with the producers and help them to achieve their objectives. 
Vol. 06, No. 05; 2021

ISSN: $2456-8643$

\section{REFERENCES}

AFOUDA Alix Servais, 2016, Contribution of women's groups to socio-economic development in the commune of Bembéréké. In revue de géographie du Laboratoire Leïdi, Université Gaston Berger, Sénégal, pp. 75-89

AFOUDA Alix Servais, ABOUDOU Ramanou and SOUNON BOUKO Boni, 2008, Fonctionnement des organisations de producteurs et développement local : cas du département du Borgou au Bénin. In Développement local et régional, Publications IRAM-LARES, Série Agriculture et Acteurs, Paris, 88 p.

DJETTO Ulrich Eugène M. and OUAGOUSSOUNON Iliassou, 2020, Contribution des organisations de producteurs à la réalisation des Infrastructures sociocommunautaires dans la commune de Banikoara. Professional degree thesis, DGAT, FLASH, UP, 61 p.

ELBEHRI Aziz and LEE Maria, 2011, The role of women producers' organizations in agricultural value chains, practical lessons from experiences in Africa and India. Report, FAO, $73 \mathrm{p}$.

FIOGBE H. L. Fréjus, 2017, Control of tax revenues for local development in the commune of Zogbodomey. Master'sthesis, MIRD, FLASH, UAC, 74 p.

GIBIGAYE ADAM Moussa, 2008, La diffusion des innovations agricoles dans le Borgou et l'Alibori : cas des Coopératives d'Utilisation de Matériel Agricole (CUMA). Thesis of unique doctorate of the University of Abomey-Calavi, EDP, FLASH, UAC, 243 p.

HOUESSOU Akoèwanou Pierre, 2020, Coopératives agricoles et développement de l'agriculture sur le Plateau d'Allada. Single doctoral thesis, EDP, FLASH, UAC, 239 p.

ILBOUDO Yelba Patrice, 2009): Le développement face à la politique de décentralisation. Master's thesis, University of Ouagadougou, 59 p.

OROU SANNOU Ramoudane, 2014, Analysis of self-financing strategies of grassroots producers' organizations: case of the communal union of producers of Gogounou. Professional degreethesis, FA, UP, 75 p.

TOHOZIN Antoine Yves, 2008, Cotonculture et développement local dans la commune de Kalalé. In Climat et Développement, Laboratoire Pierre PAGNEY - Climat, Eau, Ecosystème et Développement (LACEEDE), pp. 50-59. 